\title{
A Vulkán Gépgyár hadiipari tevékenysége Budapesten
}

A XIX-XX. század fordulóján, az Osztrák-Magyar Monarchiában a hadsereg-beszállítók száma viszonylag kevés volt. A császári és királyi (k. u. k.) közös hadügyminisztérium csak a legnagyobb gyáraktól rendelt, amelyek a nagyszámú megrendeléseket könnyen tudták teljesíteni. Ennek ellenére a kisebb üzemek folyamatosan küldték ajánlataikat, amelyekben kedvező áron vállaltak kisebb és egyszerủbb felszerelések szállítását, mint például létrákat, lócövekeket, sátorponyvákat, köteleket stb. A monarchiában a lőszergyártás állami monopólium volt. Csak az erre a célra épült lőszergyárak és néhány nagyobb gyár kapott megrendelést lőszerre. Ilyenek voltak például az osztrák Böhler (Gebrüder Böhler \& Co., Kapfenberg), a wöllersdorfi lőszergyár (K. u. k. Munitionsfabrik Wöllersdorf), a berndorfi fémárugyár (Berndorfer Metallwarenfabrik, Artur Krupp AG), a bécsi tüzérszertár gyára (K. u. k. Artillerzeugsfabrik, Bécs X., Arzenál), a cseh witkowitzi acélmű (Witkowitzer Bergbau und Eisenhütten Gewerkschaft), a Škoda (Skodawerke AG), a magyar Weiss Manfréd Rt. (Weiss Manfréd Lőszer-, Acél-, Fémmúvei Rt.), és a diósgyőri acélgyár (M. kir. Állami Vas- és Acélgyár).

Az 1900-as évek elején a nagy lőszergyárak egyre több megrendelést kaptak, amelyeknek kielégítésére egyes alkatrészeket más, kisebb gyáraktól kellett beszerezniük. Ekkor kapcsolódott be a tüzérségi hüvelyek és gránátok gyártásába az addig gyalog-
1. táblázat. 1914-től hadiipari megrendeléseket teljesítő főbb cégek

\begin{tabular}{|c|c|}
\hline A cég neve és címe & A gyártmányok megnevezése (példa) \\
\hline $\begin{array}{l}\text { Bartos Zoltán fém- } \\
\text { és bádogárugyára, } \\
\text { Budapest VII., Dongó u. } 7 .\end{array}$ & $\begin{array}{l}\text { - 8M acetilén jelzőlámpa, } \\
\text { - aknakereső csónakhoz úszó, } \\
\text { - tölténytáska-gomb. }\end{array}$ \\
\hline $\begin{array}{l}\text { Gazdasági és } \\
\text { gépfelszerelési Rt., } \\
\text { Kistarcsa }\end{array}$ & $\begin{array}{l}\text { - 14M } 10 \text { cm-es lőszeres félkocsi, } \\
\text { - egészségügyi málhás kocsi, } \\
\text { - lőszeres láda. }\end{array}$ \\
\hline $\begin{array}{l}\text { Kollerich Pál és Fiai, } \\
\text { Budapest IV., } \\
\text { Ferencz József rakpart } 21 .\end{array}$ & $\begin{array}{l}\text { - fakeretű lőporszárító szita, } \\
\text { - } 8 \text { cm-es gránáttest, } \\
\text { - drótfonat fogolytábor kerítéshez, } \\
\text { - aknavető gránáttest. }\end{array}$ \\
\hline $\begin{array}{l}\text { Latinák Jenő szerszámgyár, } \\
\text { Budapest X., Monori utca 2-4. }\end{array}$ & $\begin{array}{l}\text { - kis és közepes drótvágó olló, } \\
\text { - igazolványi jegytok, } \\
\text { - lapát, csákány, fejsze, } \\
\text { - } 8 \text { cm-es gránáttest. }\end{array}$ \\
\hline $\begin{array}{l}\text { MÁV gépgyár, } \\
\text { Budapest X., Kőbányai út }\end{array}$ & $\begin{array}{l}\text { - géppuska-pajzs, } \\
\text { - aknavető cső, } \\
\text { - } 12 \text { és } 15 \mathrm{~cm} \text {-es srapnel test, } \\
\text { - ágyúkerék. }\end{array}$ \\
\hline $\begin{array}{l}\text { Oetl Antal vasöntöde és } \\
\text { gépgyár, } \\
\text { Budapest X., } \\
\text { Asztalos Sándor út 18-20. }\end{array}$ & $\begin{array}{l}\text { - hordozható hegyi sütőkemence alkatrész, } \\
\text { - puskagránát, } \\
\text { - fokos, } \\
\text { - vasszerkezet, repülőgép gyártáshoz. }\end{array}$ \\
\hline Reiter Ödön kocsigyár, Vác & $\begin{array}{l}\text { - 3M málhakocsi, } \\
\text { - 5M } 8 \text { cm-es lőszeres taliga. }\end{array}$ \\
\hline $\begin{array}{l}\text { Schlick-Nicholson Gép-, } \\
\text { Waggon, Hajógyár Rt. } \\
\text { Budapest VI., Váci út } 45 .\end{array}$ & $\begin{array}{l}\text { - 86M lőszerkocsi, } \\
\text { - utász-szerkocsi, } \\
-7,5 \mathrm{~cm} 15 \mathrm{M} \text { gránáttest, } \\
-8 \mathrm{~cm} 8 \mathrm{M} \text { srapnel test, } \\
-8 \text { és } 10 \mathrm{~cm} 14 \mathrm{M} \text { gránáttest. }\end{array}$ \\
\hline
\end{tabular}

ÖSSZEFOGLALÁS: Az Osztrák-MagyarMonarchiában a lőszergyártás állami monopólium volt. A háború alatt a nagy lőszergyárak egyre több megrendelést kaptak. A gyújtószerkezetek lószerelemnek számítottak, ezért a gyártásuk államilag felügyelt lószergyárakban vagy külön erre a célra létrehozott üzemekben folyt. llyen volt a csepeli Weiss Manfréd Rt. egyik beszállítója a budapesti Vulkán Gépgyár Rt., amely 1906-ban a milánói világkiállításon Grand-prix dijat nyert.

KULCSSZAVAK: Osztrák-Magyar Monarchia, Vulkán Gépgyár, I. világháború, hadiipar
ABSTRACT: In the Austro-Hungarian Monarchy, ammunition manufacturing was a state monopoly. In the course of the war, the ammunition factories received more and more orders. The primer was considered an element of the ammunition, therefore, they were produced in state-supervised ammunition factories or in plants established especially for this purpose. The Vulkán Machine Factory Joint-stock Company, one of the subcontractors of the Weiss Manfréd JSC, was such an entity, which won Grand Prix medal at the world's fair held in Milan in 1906.

KEY WORDS: Austro-Hungarian Monarchy, Vulkán Machine Factory, World War I, defence industry 

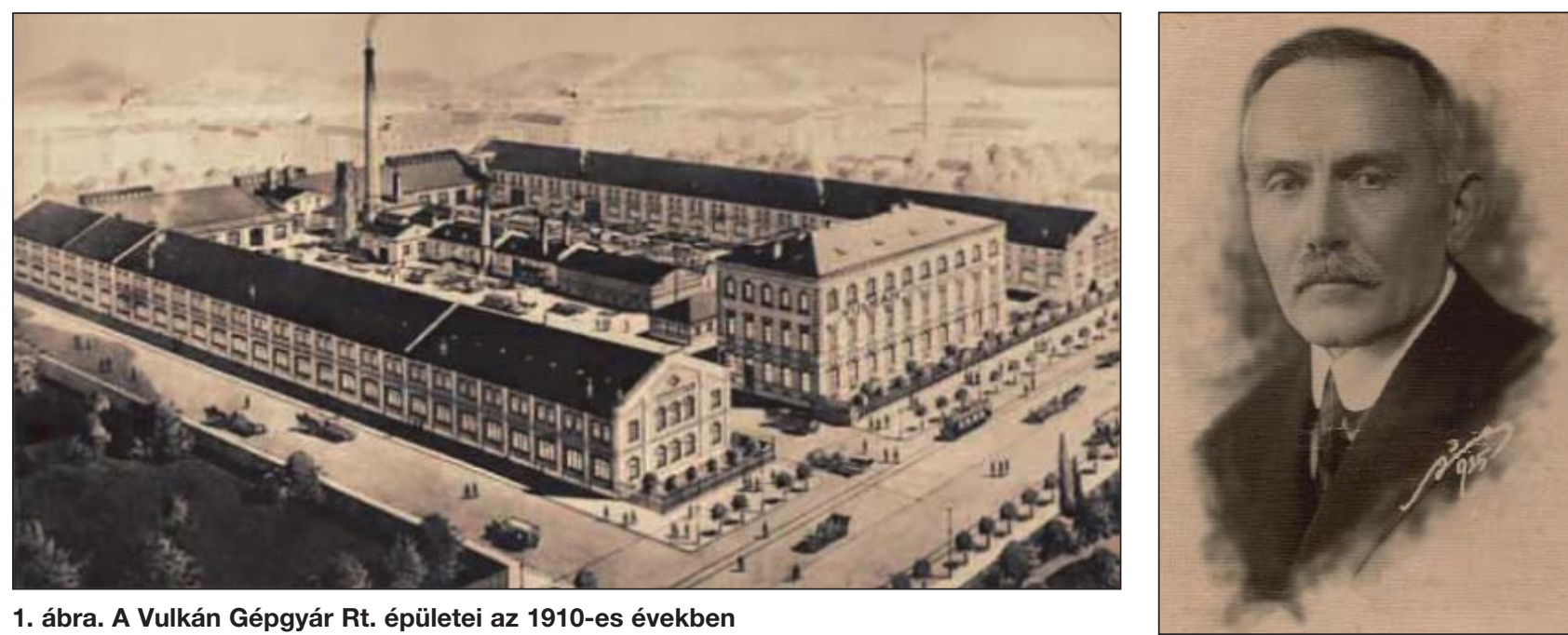

1. ábra. A Vulkán Gépgyár Rt. épületei az 1910-es években

sági lőszerek gyártásával foglalkozó bécsi Georgh Roth (Georgh Roth AG), ekkor kezd tüzérségi gránátokat gyártani a kladnói Poldi (Poldi-Hütte Edelstahlwerk), az 1905-ben alapított enzesfeldi lőszergyár (Enzesfelder Munitions und Metallwerk AG) és a komoraui vasgyár (Eisenwerke Komorau, C. T. Petzold \& Co.) is. A tüzérségi és aknavető gránátok egyik legfontosabb eleme a gyújtószerkezet. A gyújtószerkezetek lőszerelemnek számítottak, ezért a gyártásuk államilag felügyelt lőszergyárakban vagy külön erre a célra létrehozott üzemekben folyt. Ilyenek voltak például a bécsi tüzérszertár (K. u. k. Artilleriezeugsfabrik Bécs X., Arzenál), a hirtenbergi Fridolin Keller (Fridolin Keller Metallwarenfabrik), a magyaróvári tölténygyár (Hirtenbergi Tölténygyár Magyar-Óvári gyára), az enzesfeldi lőszergyár (Enzesfelder Munitions und Metallwerk AG) és a budapesti Vulkán gépgyár (Vulkán Gépgyár Rt.).

A háború kitörésekor szinte az összes gyárat és üzemet, még a legkisebbeket is katonai felügyelet alá vonták. Ezek a kapacitásuknak és rendeltetésüknek megfelelően a hadsereg részére is gyártottak. A megrendelések zökkenőmentes teljesítése érdekében a gyár, üzem vezetősége mellé katonai vezetőt is kirendeltek.

A bevezetőből kiemelve, továbbiakban e cikk részletesen csak a Vulkán Gépgyárral foglalkozik. A gépgyár története 1893-ban kezdődött, amikor a bécsi származású Friedrich

2. ábra. A Vulkán Gépgyár egyik épületszárnyának homlokzata a Váci úton

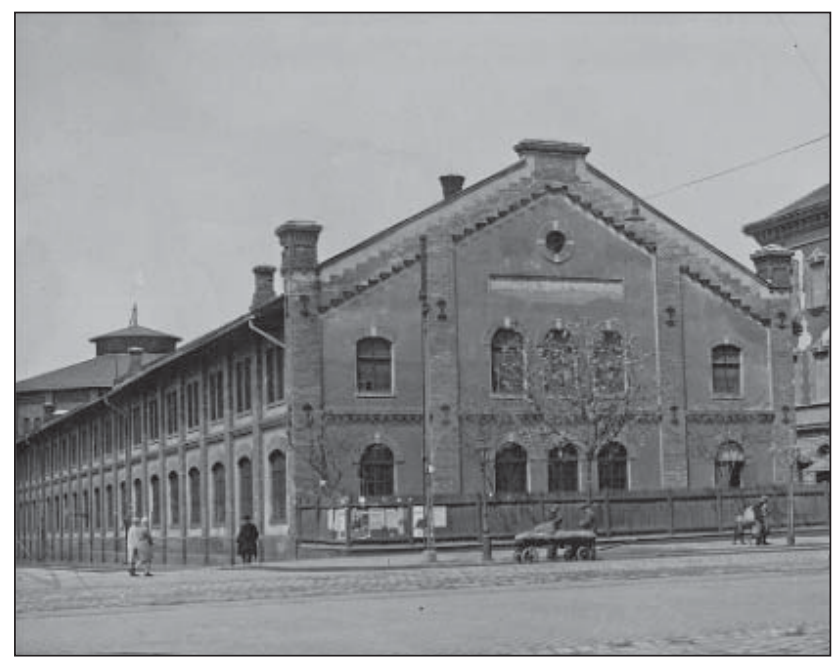

3. ábra. Bohaček Ottokár gépészmérnök portréja 1925-ből. A Vulkán Gépgyár Rt. tervezőmérnöke, majd igazgatója, később a Magyar Vasmúvek és Gépgyárak Országos Egyesülete Általános Gépgyártási Szakosztályának elnöke volt

4. ábra. A gyár 1911-es reklámja

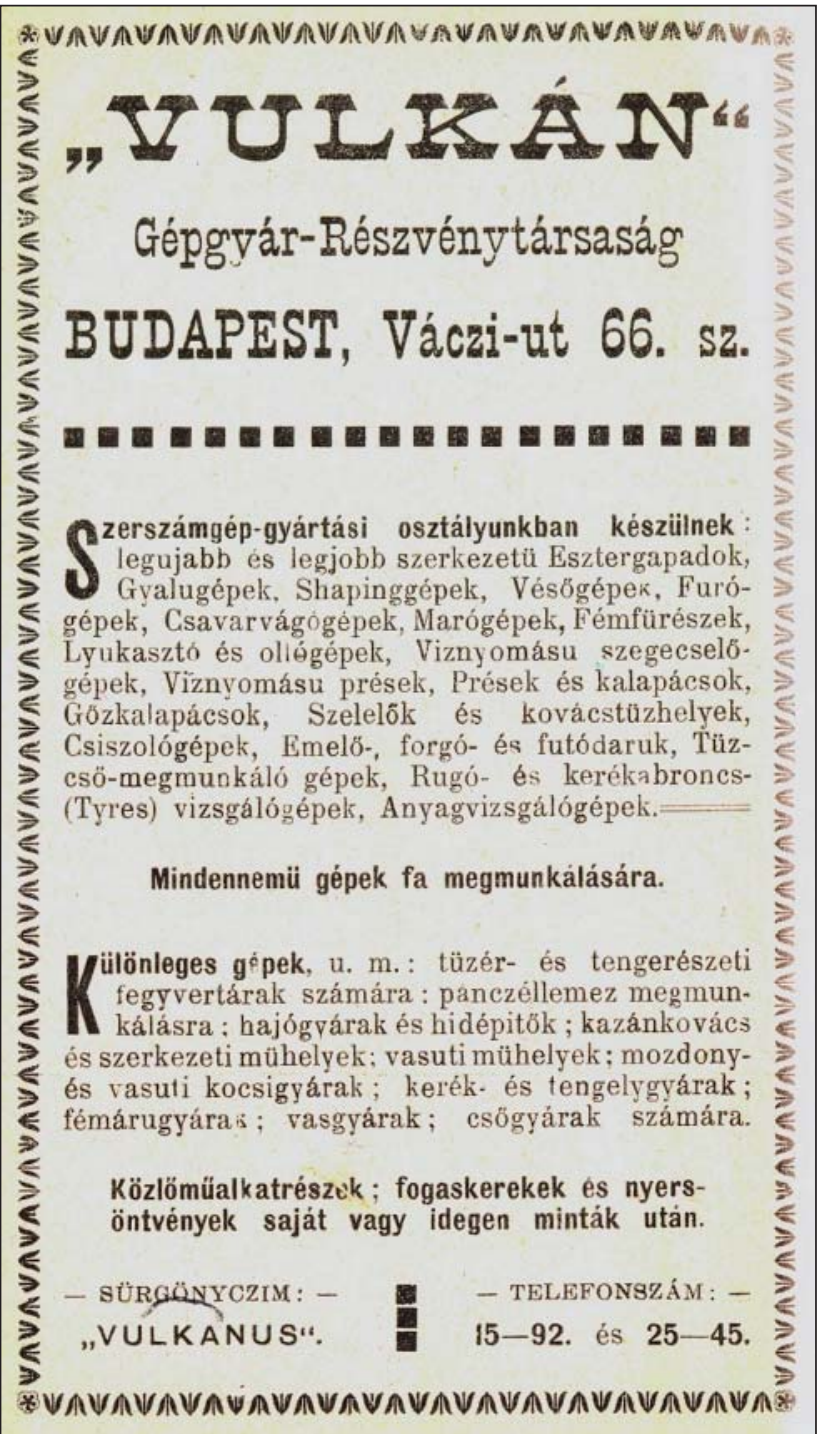




\begin{tabular}{|c|c|c|c|}
\hline "Valken" & \multicolumn{3}{|c|}{ 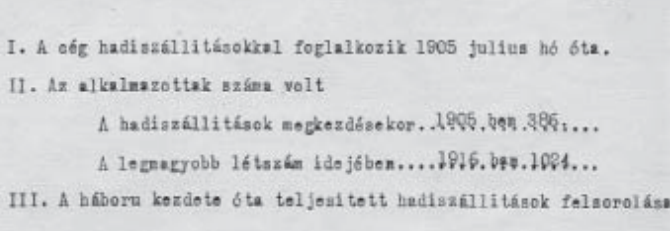 } \\
\hline $\begin{array}{l}\text { Dapabszim } \\
\text { vagy suly }\end{array}$ & $\begin{array}{l}\text { A szalli tott ipereikeok } \\
\text { nognovorose }\end{array}$ & $\begin{array}{l}\text { Darabezkan } \\
\text { vagy suly }\end{array}$ & $\begin{array}{c}\text { A szallit tott ipateil } \\
\text { megrevezisse }\end{array}$ \\
\hline 476 dipb. & eszengrapad & 200000 kíg 21 & $15 \mathrm{~N} .2$ Gean.caralté \\
\hline $190 \quad$ & furógép & $200000 \quad " 1$ & S7 m.3.Granat \\
\hline $248 "$ & frikt. 68 oxont.nzito & 100000 ." & 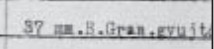 \\
\hline$\infty \quad "$ & narozép & 50000 of & Exuitó kerene 15 of \\
\hline 37. & gyelugép. & & W.14 Orantit Sohrovane1 \\
\hline $75 \quad 11$ & ves segép. & & \\
\hline $65 "$ & harint tog alugép & & \\
\hline $78 \quad$ & ooinzológép & & \\
\hline $2666^{\circ}$ & 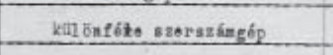 & & \\
\hline 910000 & kazt. 10 enf.t .99 schrap.gyult & & \\
\hline $25000 \mathrm{db}$. & 47 ma. Brenit pqujto & & \\
\hline $4100 "$ & 10.96 k. Pon $6 k$ byujts & & \\
\hline $62500 \quad "$ & 8 on. aseppentṕ gyojtó & & \\
\hline $50000 \mathrm{kfos}=1$ & boles alkatr. $8 \mathrm{~cm} .1 \mathrm{l} .15$ prani & & \\
\hline & goujtohor. & & \\
\hline 200000 " & 10.0 X.14 G.Sehrep. aruitió & & \\
\hline
\end{tabular}

\section{5. ábra. Az 1914-16 között teljesített hadiszállítások jegyzéke}

Fernau, a Reinhard Fernau \& Co. cég Vulkán Gépgyárának tulajdonosa megszerezte a budapesti Gutjahr és Müller

\section{6. ábra. DPSg eszterga a szerszámzatával és két nyers} $47 \mathrm{~mm}$-es gránáttesttel

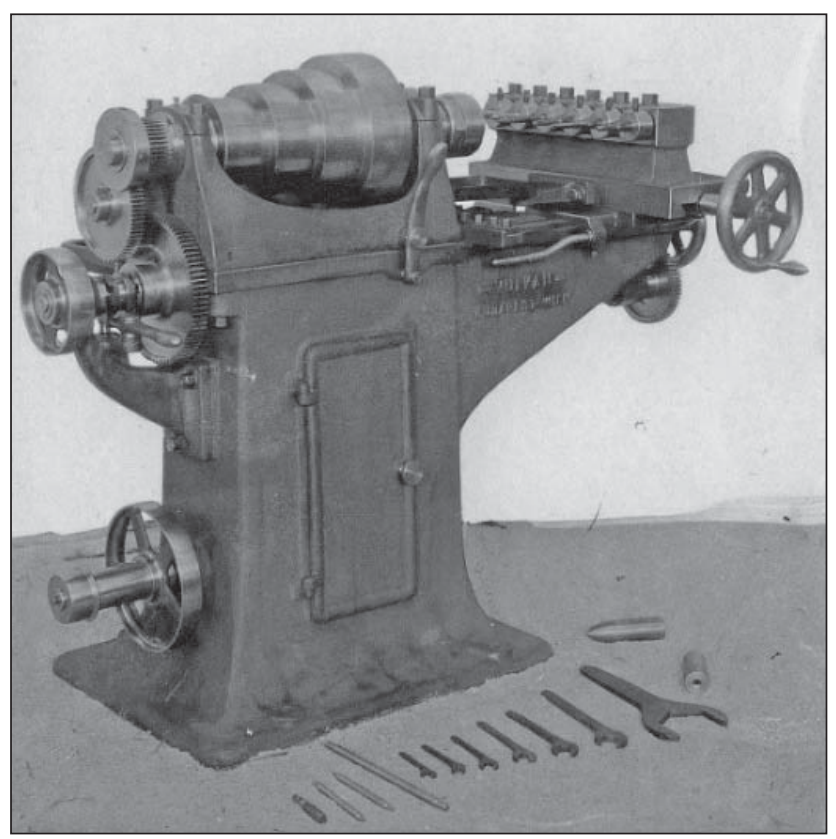

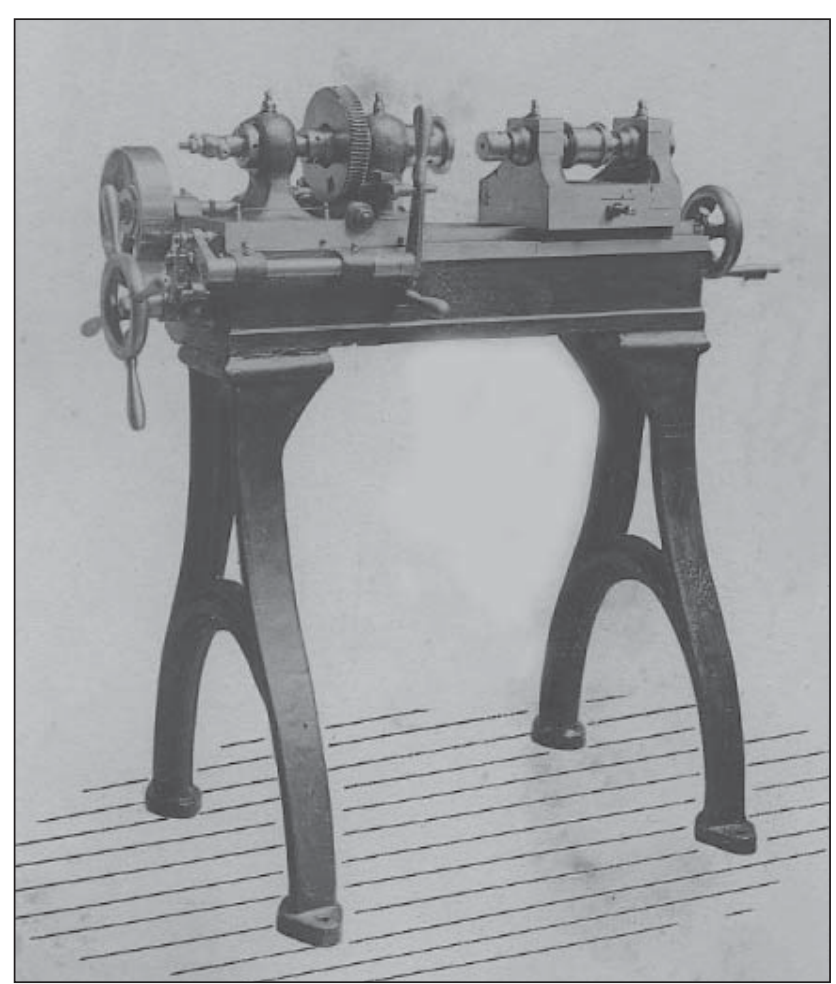

\section{7. ábra. FSpZ marógép}

Malomipari Gépgyár tulajdonának 60\%-át. Banki segítséggel létrejött a Vulkán Gépgyár Részvénytársaság, azelőtt Gutjahr és Müller, Reinhard Fernau \& Co. nevű vállalat bécsi és immár budapesti gyárakkal. A gyárak fő profilja szerszámgépek, malomberendezések, gőzkazánok, öntöttvas szerkezetek tervezése és kivitelezése volt. A budapesti gyár az 1890-es években inkább a kő-, fa- és fémmegmunkáló szerszámgépek gyártását végezte. A gyár címe ekkor Külső-Váczi út 70 volt. A gyár sikerében nagy szerepe volt Bohaček Ottokár (1870. január 16. Sedlec 1937. október 1. Budapest) gépészmérnöknek, aki 1890ben a prágai Műszaki Főiskola elvégzése után a bécsi Vulkán Gépgyár tervező mérnöke lett. 1894-ben került a budapesti gyárba, ahol műszaki szerkesztő, majd 1908-tól főmérnök, 1912-től műszaki igazgató, a gyártmányszerkesztés vezetője és a gyár vezetője lett. Az ő irányításával a gyár mintegy 250 különféle típusú szerszámgépet gyártott, hozzávetőleg $2100 \mathrm{db}$-os mennyiségben. Főbb alkotásai az addig még ismeretlen portálmarógép, az elektromágneses tengelykapcsoló és az Erzsébet-híd elemeinek

\section{8. ábra. D240-es lövedékeszterga}

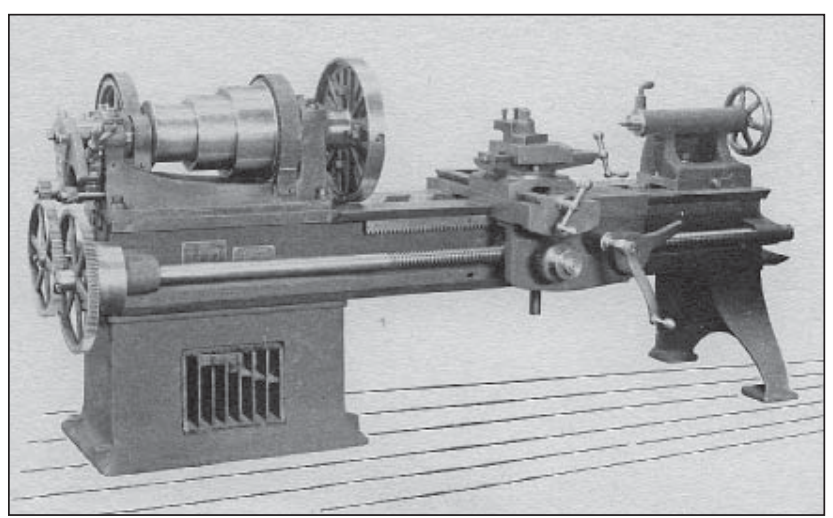


2. táblázat. A budapesti Vulkán Gépgyárban készült gránáttestek és gyújtószerkezetek

\begin{tabular}{|c|c|}
\hline 25 mm-es páncéltörő lövedék & 25 mm-es szórólöveghez \\
\hline 37 mm-es repeszgránát ( $37 \mathrm{~mm} \mathrm{Z}$. Gr.) test & $\begin{array}{l}37 \text { mm-es 1900M hajófedélzeti automata ágyúhoz, } \\
37 \text { mm S. F. K. L/23 hajófedélzeti gyorstüzelő ágyúhoz }\end{array}$ \\
\hline 37 mm-es páncéltörő gránáttest (37 mm St. Z. Gr.) & $\begin{array}{l}37 \text { mm-es 1900M hajófedélzeti automata ágyúhoz és } \\
1915 M \text { gyalogsági ágyúhoz }\end{array}$ \\
\hline $\begin{array}{l}37 \text { mm-es } 1915 \mathrm{M} \text { repeszgránát ( } 37 \text { mm M15 B. Gr.) test } \\
\text { gyújtószerkezettel }\end{array}$ & 1915M gyalogsági ágyúhoz \\
\hline 47 mm-es páncéltörő gránáttest (47 mm Z. Gr.) & 47 mm-es S. F. K. L/44 hajófedélzeti gyorstüzelő ágyúhoz \\
\hline 96kM K/12 fenék gyújtószerkezet & 47 mm-es páncéltörő gránáthoz (47 mm Z. Gr.) \\
\hline 10 cm 99M srapnel kettős gyújtószerkezet & $10 \mathrm{~cm} 1899 \mathrm{M}$ srapnelhez \\
\hline 10 cm 99M gránát kettős gyújtószerkezet & 10 cm 1899M gránáthoz \\
\hline 10 cm 14M G-srapnel kettős gyújtószerkezet & 10 cm 1914M G-srapnelhez \\
\hline 10 cm 15M srapnel kettős gyújtószerkezet & 10 cm 1915M gránáthoz \\
\hline 15 cm 14M G-srapnel kettős gyújtószerkezet & 15 cm 1914M G-srapnelhez \\
\hline $5 \mathrm{M}$ gránát kettős gyújtószerkezet & 8 cm-es 1905M gránáthoz \\
\hline 8M srapnel kettős gyújtószerkezet & 7.5 és $8 \mathrm{~cm}$-es srapnelekhez \\
\hline 12M srapnel kettős gyújtószerkezet & $10,12,15 \mathrm{~cm}$-es srapnelekhez \\
\hline 15aM gránát gyújtószerkezet & $7.5,8,9,10,12,15 \mathrm{~cm}$-es öntöttvas gránátokhoz \\
\hline
\end{tabular}

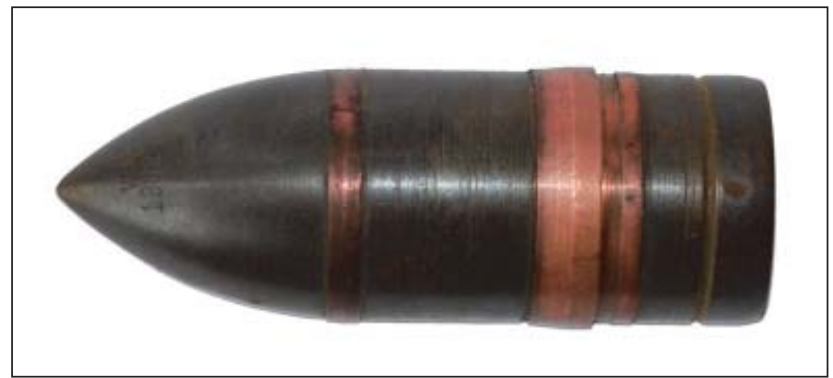

9. ábra. 37 mm-es St. Z. Gr. 1908-ból

megmunkálásához szükséges gépek. 1905-től a gyár a rövidebb és ismertebb Vulkán Gépgyár Rt. nevet viseli. Ekkor kapott megbízást tüzérségi gyújtószerkezetek gyártására. A budapesti gyárban készült gyújtószerkezetek „VB” (Vulkán-Budapest), a bécsi gyárban készültek „VW” (Vulkan-Wien) jelölést kaptak. 1906-ban a milánói világkiállításon Grand-prix díjat nyert. 1911-ben már páncélleme-

10. ábra. 47 mm-es Z. Gr. a hozzá tartozó $96 \mathrm{kM}$ gyújtószerkezettel, 1915-böl

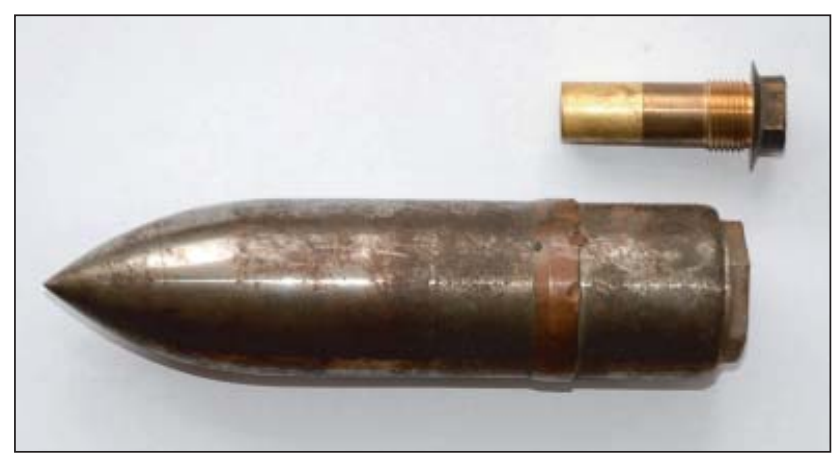

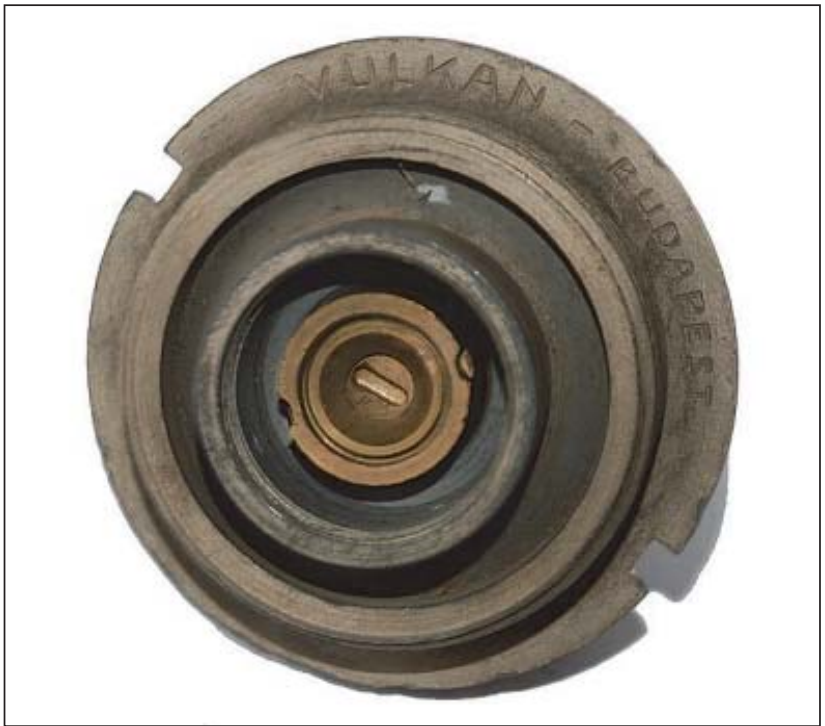

11. ábra. $10 \mathrm{~cm}$-es $15 \mathrm{M}$ gránát kettős gyújtószerkezet Vulkan felirattal

zek megmunkálását végző gépeket is gyártottak. 1912-re a gyárban működő gépek $80 \%$-a saját gyártású volt. A világháború kitörése előtt a gyár támogatás hiányában nem tudott fejlődni, ezért a termelés csökkeni kezdett. 1914ben katonai felügyelet alá helyezték, mind a 2000 dolgozójával együtt. Címe ekkor már V. ker. Váczi út 66. A gyár feladata a hadiipari gyárak részére szükséges automata gépek tervezése és gyártása volt, de emellett üres gyújtószerkezeteket és kis kaliberű $(37,47 \mathrm{~mm})$ tengerészeti gránáttesteket is készített. Az itt elkészült gyújtószerkezeteket és gránáttesteket a nagyobb lőszergyárakba szállították, ahol lőporral, illetve robbanóanyaggal élesre szerelték. 


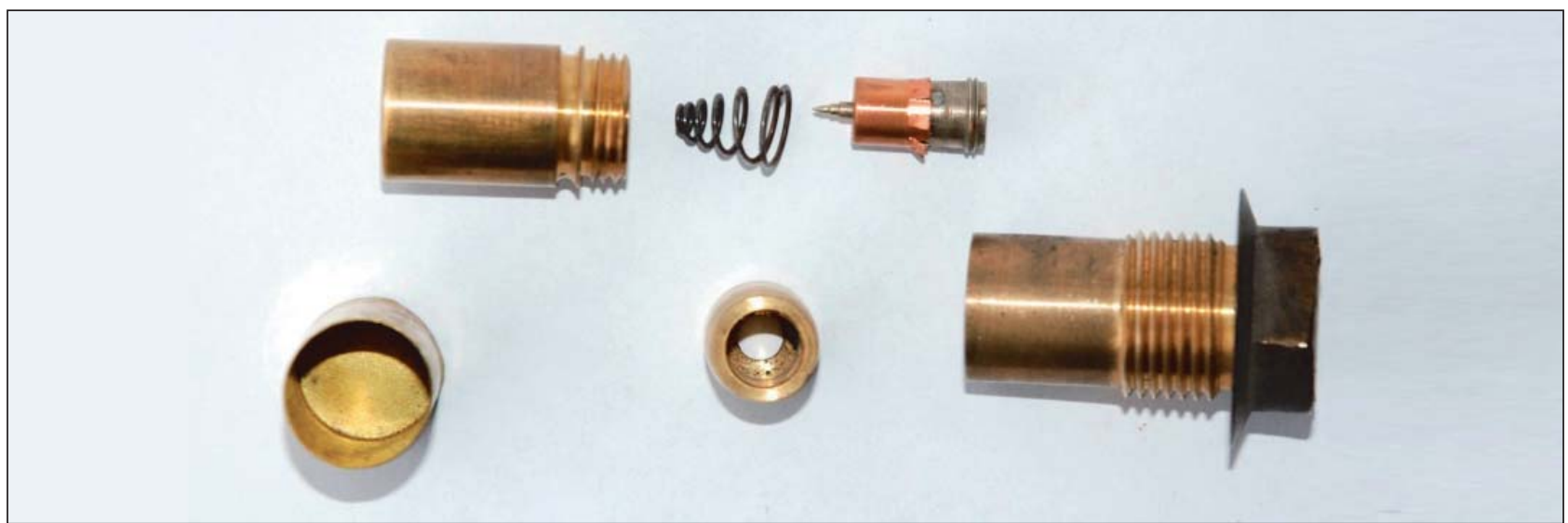

\section{2. ábra. A 96kM fenékgyújtó-szerkezet elemei}

E tekintetben a Vulkán a csepeli Weiss Manfréd Rt. egyik beszállítója volt.

A háború idején létrejött a gyár srapnel-osztálya, ahol a srapnelek gyújtószerkezeteit és a srapnelek gyártásához szükséges gépeket gyártották. Itt készült a csepeli Weiss Manfréd Rt. részére az ólom srapnel golyók előállítását végző prés is. A gránátok gyártásához szükséges gépeket a bécsi gyár készítette. Ilyen volt például a $47 \mathrm{~mm}$-es gránátok belső megmunkálására szolgáló DPSg eszterga és a gyújtószerkezetek korongjainak a marását végző FSpZ marógép.

1915 végén a Kollerich Pál és Fiai első magyar sodronyszövet és szitaárúgyára is bekapcsolódott a lőszergyártásba. A gyártás beindításához november 30-án 1096 korona értékben vásároltak a Vulkán gépgyártól öntvényeket, csapágyakat, tengelykapcsolókat, december 31-én pedig 2565 koronáért egy DRs 2 típusú revolveresztergát és 5190 koronáért két darab D240-es lövedékesztergát.

Az 1914-15-ös évekről szóló üzleti jelentések alapján a gyár 495578 korona nyereséget ért el, amelynek egy részét a dolgozók ellátására fordították. A következő évben a budapesti gyár nyeresége 689.315 korona, a bécsi gyáré 1003848 korona volt. A tisztviselők ellátási alapja 200000 koronát, a dolgozoké szintén 200000 koronát kapott, míg a hadsegélyezési alapba 100000 korona jutott. 1917-ben a két gyár együttes nyeresége majdnem elérte a 2 millió koronát, amelyből a tisztviselőknek 200000 koronát, a

13. ábra. 15 cm-es 14 M G-srapnel kettős gyújtószerkezet az alsó zárólapjával

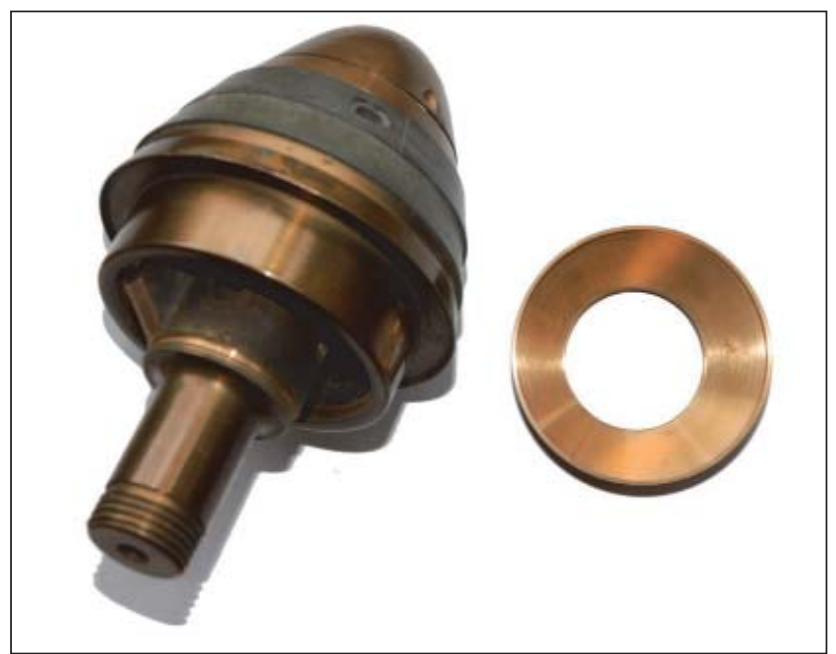

dolgozók ellátási alapjának szintén 200000 koronát utaltak, míg a hadsegélyezési alapba ismét 100000 korona jutott. Ezen felül az igazgatóság részére 60000 koronát utaltak ki. Az 1918. július 20-án tartott 24. minisztertanácsi ülésen a kereskedelemügyi miniszter javaslatot terjesztett fel a magyar hadiipari vállalatok dolgozóinak kitüntetésére. A felterjesztés alapján Boschan Lipót főmérnök III. osztályú, 19 dolgozó pedig IV. osztályú, Polgári Hadiérdem-keresztet kapott. November 4-én a magyar hadügyminiszter 28206. elnöki 9a számú rendelete alapján a lőszergyártást beszüntették.

A háború utáni éveket a gyár viszonylag jól viselte. 1920ban a tulajdon 80\%-a a Magyar Általános Hitelbank tulajdonába került. Ekkor fejlesztették a vasöntödét. A '20-as évek végén a belföldi kereslet visszaesése miatt a gyár a szovjet és román piacra is termelt. 1929 májusában Bohaček Ottokárt a Magyar Vasművek és Gépgyárak Országos Egyesülete Általános Gépgyártási Szakosztályának az elnökévé választották. A gazdasági válság miatt a gyár is veszteségessé vált. Mivel a hitelbank nem nyújtott több hitelt, a gyár megszűnt, helyét a Bohacsek testvérek Szerszámgépgyára vette át. A gyár az 1940-es években az Újpest rakpart 60 . szám alá költözött, majd a II. világháború után államosították. Ezt Bohaček Ottokár már nem érte meg. Népes családot hagyott maga mögött és számtalan levédett találmányt. A régi Váci úti gyár napjainkra teljesen eltűnt.

(Köszönetünket fejezzük ki Bohacsek Ottokárnak, Bohaček Ottokár dédunokájának a segítségért és a cikkben szereplő képekért.)

\section{FORRÁSJEGYZÉK}

Bencze Géza: Váci út, a magyar gépipar főutcája, Országos Pedagógiai Könyvtár és Múzeum, Budapest 2006;

Műszaki naptár 15. évfolyam, 1911;

Elektrotechnika folyóirat, 1916. március1.;

Elektrotechnika folyóirat, 1917. április 5.;

Elektrotechnika folyóirat, 1918. június 1.;

Hadtörténeti Intézet és Múzeum, Hadtörténeti Levéltár: HM fond 1916 ált.;

Hadtörténeti Intézet és Múzeum, Hadtörténeti Levéltár: HM fond 1918 eln.;

Magyar Nemzeti Levéltár: K27 fond Minisztertanácsi iratok 1918;

Budapest Fővárosi Levéltár, XI. 119 fond 4. doboz Kollerich Pál és fiai iratai. 